\title{
Comparative in vitro cytotoxic, anti- inflammatory and anti-microbiological activities of two indigenous Venda medicinal plants
}

\author{
M. T. Sigidi ${ }^{*}$, C. P. Anokwuru², T. Zininga ${ }^{3}$, M. P. Tshisikhawe ${ }^{4}$, A. Shonhai ${ }^{3}$ I. D. I. Ramaite², A. N. Traoré \\ and N. Potgieter ${ }^{1,5}$
}

\begin{abstract}
Background: The Vhembe region of the Limpopo province has a rich tradition of medicinal plants use. Traditionally, boiled roots of Ziziphus mucronata are used in the treatment of boils, general swelling and other skin infections. A combination of leaf paste and root infusion treats measles, dysentery, chest complains, and gland swelling. Pterocarpus angolensis is famous for the treatment of menorrhagia, infertility in women, wounds and pain management. The purpose of the present study was to compare the cytotoxicity, anti-inflammatory potential and anti-microbial activities of Ziziphus mucronata and Pterocarpus angolensis from the Vhembe region.
\end{abstract}

Method: U937, MeWo, Vero and RAW 264.7 cells were treated to various concentrations (50, 100, or 125 or $250 \mu \mathrm{g} / \mathrm{ml}$ depending on assays) of Ziziphus mucronata and Pterocarpus angolensis. Cytotoxicity assay was done using MTT; Antiinflammatory activity was assessed using NO production; Anti-bacterial activity was done using the Micro-Broth dilution method and Anti-mycobacteria activity was determined using the Alamar Blue Method while RT activity was measured by ELISA.

Results: Cytotoxicity results showed that Pterocarpus was more toxic than Ziziphus as observed in the Vero and MeWo cells; however both displayed toxicity towards a Human cancer cell line. Both extracts did not inhibit nitrate production but induced significant increase in macrophage activation. The plant extracts have shown anti-tuberculosis activity at concentrations $>500 \mathrm{\mu g} / \mathrm{ml}$ and there was moderation inhibition of HIV replication.

Conclusions: The results obtained indicated that the extracts have pro-inflammatory properties, and the observed toxicity on malignant cell lines must be investigated further for promising anti-cancer drug therapy.

Keywords: Medicinal plants, Ziziphus mucronata, Pterocarpus angolensis, Cytotoxicity, Cancer

\section{Background}

The use of medicinal plants has been recorded for centuries with consistency regarding their uses as well as effectiveness in the treatment of diseases [2]. The use of traditional medicines by traditional healers has played an important role in the health care of millions of people. The diversity of about 24,000 indigenous plants in South Africa contributes an estimate of $10 \%$ of higher plants

\footnotetext{
* Correspondence: muendi.sigidi@yahoo.com

'Microbiology Department, University of Venda, Private Bag X5050,

Thohoyandou, Limpopo Province, South Africa

Full list of author information is available at the end of the article
}

on globally [24]. The majority of people in South Africa rely heavily on the traditional use of medicinal plants with an estimated $70 \%$ of the population using one or more of the approximate 3000 species of plants used as traditional medicines [24, 33, 35].

Ziziphus mucronata Willd is commonly known as buffalo thorn (Mukhalu), it belongs to the Rhamnaceae family and is found in most parts of the country [10, 29]. Traditionally, boiled roots concotions are used in the treatment of boils, general swelling and other skin infections. A combination of leaf paste and root infusion treats measles, dysentery, chest complains, and gland 
swelling. Bark infusions are known to treat coughs ([5]; [35-37]; [14, 18]). The active ingredients are several alkaloids known as peptide alkaloids such as mucronine D [34].

Pterocarpus angolensis DC belongs to the family Fabaceae, it is commonly known as bleedwood tree (Mutondo). Bark infusions are dropped into aching ear to neutralize the pain, boiled extract can be taken orally for menorrhagia [19]; roots infusions are used as a remedy for infertility amongst women [19]. Mutondo is also known for its popular use in treatment of eye infections [19], wounds and psoriasis [14]. The value of its timber carries a lot of weight amongst the African cultures since it is easy to work with for furniture, implements and curios purposes. Mutondo is also employed in the construction of canoes because the wood does easily shrink or swell much. The African women mixes the red sap with fresh animal fat to make a cosmetic for faces and bodies to enhance their beauty. It is also believed to have magical properties with regards to cleansing human blood from different ailments and spiritual possessions'; the belief is due to the red sap close resemblance to blood.

In the current study, we evaluated the claim by traditional healers of these two plants' biological activities.

\section{Methods}

\section{Description of plant materials}

Stem Barks of Ziziphus mucronata (MPT00123) and Pterocarpus angolensis (MPT00118) were collected in 2014 in their natural habitat in the Vhembe District of the Limpopo Province (South Africa). The collected plants were identified using their vernacular names and later confirmed by the taxonomic rank at the Department of Botany, University of Venda with reference to the international plant name index (Ziziphus mucronata Willd and Pterocarpus angolensis DC). The samples were deposited in the departmental herbarium.

Bark samples for each plant were air dried and ground to fine powder using a Buchi mixer (Buchi Labortechnik AG, Flawil, Switzerland). The powder was carefully stored in a cool dry place until further use. Water soluble extracts were prepared by soaking $50 \mathrm{~g}$ of each samples in hot water $(900 \mathrm{ml})$ and allowed to stand overnight. The homogenate was filtered using Whatman filter paper (110 mm, Sigma Aldrich) then freeze dried (FTS systems, Stone Ridge, NY; USA) to obtain 20 g of crude extracts. Unless indicated, plant extracts were solubilized in dimethyl sulfoxide (DMSO) to a stock concentration of $50 \mathrm{mg} / \mathrm{ml}$ and stored at $4{ }^{\circ} \mathrm{C}$ until required.

\section{Cell cultures}

Ethical clearance was obtained from the University of Venda, Research and Ethics committee. The human macrophage cell line U937 (ATCC ${ }^{\bullet}$ CRL1593.2), Mewo
(ATCC ${ }^{\ominus}$ HTB 65), Vero (ATTC CCL 81) and the Murine macrophage RAW 264.7 cells (ATTC ${ }^{\bullet}$ TIB 71) were maintained in Roosevelt Park Memorial Institute medium (RPMI, Sigma Aldrich'; St Louis, MI; USA) or Dubelco's modified Eagle Media (DMEM; Sigma Aldrich; St Louis, MI; USA) respectively. The media were supplemented with $10 \%$ foetal bovine serum and $0.01 \%$ Gentamycin Sulfate (Sigma Aldrich, St Louis, MI, USA).

\section{Cytotoxicity assay}

The method described by Klos et al. [16] was used. Three cell lines (U923, Mewo and Vero Cells) were used in this assay. The cells were seeded at a density of 10 000 cells/well (U937) or 6000 cells/well (MeWo/Vero) in 96-well plates (NUNC, Rochester, NY, USA) and incubated for overnight at $37{ }^{\circ} \mathrm{C}$ in a humidified $5 \% \mathrm{CO}_{2}$ incubator (Thermofisher, Waltham, MA, USA). Samples were tested in two concentrations, $125 \mu \mathrm{g} / \mathrm{ml}$ and $250 \mu \mathrm{g} / \mathrm{ml}$ for U937cells and $50 \mu \mathrm{g} / \mathrm{ml}$ and $100 \mu \mathrm{g} / \mathrm{ml}$ for the MeWo/Vero cells for optimal results as obtained from Prof Van Der Venter's Lab (Bioassaix, Nelson Mandela Metropolitan University, PE, South Africa). After adding the plant samples, the plates were further incubated for $48 \mathrm{~h}$. Melphalan (Glaxo-smithkline, Paris, France) was used a positive known toxic chemical.

At the end of the incubation period, the medium was removed from the adherent plate (MeWo/Vero) and replaced with fresh DMEM containing methylthiazol tetrazolium (MTT) at a final concentration of $0.5 \mathrm{mg} / \mathrm{ml}$ [22] and for the suspension plate (U937 cells) $20 \mu \mathrm{l}$ of MTT was added per well to also get a final concentration of $0.5 \mathrm{mg} / \mathrm{ml}$. The plates were again incubated for a further $3 \mathrm{~h}$ to allow reduction of MTT and then the formed crystals were solubilized by adding DMSO with gentle shaking for $15 \mathrm{~min}$. Absorbance was read at $560 \mathrm{~nm}$ using a multiwall scanning spectrophotometer (Multiscan MS, Labsystems; Vienna, Virginia, USA). The percentage of inhibition was calculated as previously reported by Huda-Faujan et al. [13] as per equation:

$\%$ Cell inhibition $=100-\frac{\text { Absorbance value of treated cells }}{\text { Absorbance value of control cells }} \times 100$

\section{Anti-inflammatory activity}

RAW 264.7 cells were seeded at a density of 25000 cells/ wells in a 96-well microtitre plate (NUNC, Rochester, NY, USA) and allowed to attach overnight. Plant extracts (50 and $100 \mu \mathrm{g} / \mathrm{ml}$ ) in complete DMEM medium were added to replenish the spent culture medium in each well. In order to stimulate macrophages, $50 \mu \mathrm{l}$ of lipopolysaccharide (LPS; $10 \mu \mathrm{g} / \mathrm{ml}$ ) containing medium was added to specific wells whereas for unstimulated macrophages, $50 \mu \mathrm{l}$ of complete medium without LPS was added to the other wells. A well-known inhibitor of nitric oxide 
(Aminoguanidine, $\left[1 \times 10^{6}\right]$; Sigma Aldrich, St Louis, Missouri, USA) served as a positive control. To assess the pro-inflammatory potential. The plates were further incubated for an hour. To quantify the production of nitric oxide $(\mathrm{NO})$ in both stimulated and non-stimulated cells, $50 \mu \mathrm{l}$ of the spent culture medium was transferred to new 96 well plates and an equal amount of Griess reagent (Roche Diagnostics, Risch-Rotkreuz, Switzerland) added. Absorbance was measured at $510 \mathrm{~nm}$ and results compared to the respective controls. Cell viability was also assessed using the MTT assay to rule out toxicity as a contributory factor to NO production.

\section{Anti-microbiological activities}

This section describes the following tests done: Antibacterial, anti-mycobacterial and anti-HIV activities.

\section{Anti-bacterial activity}

There are numerous established methods for the screening of biological extracts for potential antimicrobial activity [9, 28]. For this study, The Eloff [9] method was used.

Five clinical strains Enterococcus faecalis, Escherichia coli, Klebsellia Pneumoniae, Salmonella enterica and Streptococcus agalactiae were grown in Mueller-Hinton $(\mathrm{MH})$ broth while the media for S. agalactiae was supplemented with $10 \%$ horse serum. The strains were inoculated in the $\mathrm{MH}$ broth $(20 \mathrm{ml})$ and allowed to grow overnight for $16 \mathrm{~h}$ in an orbital incubator (EcoTherm, Hartkirchen, Austria) $37^{\circ} \mathrm{C}$. Gentamicin sulfate $(2 \mathrm{mg} / \mathrm{ml}$; Sigma Aldrich) and vancomycin hydrochloride $(2 \mathrm{mg} / \mathrm{ml}$; Sigma Aldrich) were used against both Gram negative and Gram positive bacteria respectively for controls. Due to Salmonella resistance to gentamicin sulfate, imipinem dehydrate, penicillin $G$, chloramphenicol and ampicillin were tested as additional antibiotics.

The two plant extracts were dissolved in DMSO at a stock concentration of $50 \mathrm{mg} / \mathrm{ml}$. From the stock solutions, a working concentration $(4 \mathrm{mg} / \mathrm{ml})$ was prepared in $\mathrm{MH}$ broth and filter sterilized (Merck, Darmstadt, Germany). The experiment was carried out as previously described by Eloff [9].

\section{Anti-mycobacterial activity}

The Mycobacterium tuberculosis H37 strain was obtained from the National Health Laboratory services (NHLS; Port Elizabeth; South Africa) and was grown in a culture broth containing Difco ${ }^{\mathrm{TM}}$ Middlebrook $7 \mathrm{H} 9$ broth (Difco, Franklin Lakes, NJ; USA), glycerol (Sigma Aldrich; St Louis, MI, USA), Tween 80 (Sigma Aldrich, St Louis, MI; USA) and Middlebrook albumin-dextrosecatalase growth supplement (Sigma) at $37{ }^{\circ} \mathrm{C}$ for $10 \mathrm{~d}$. Rifampicin $(1 \mathrm{mg} / \mathrm{ml})$ and ethambutol dihydrochloride (2 $\mathrm{mg} / \mathrm{ml})$ were dissolved at stock concentration of
$1 \mathrm{mg} / \mathrm{ml}$ and $2 \mathrm{mg} / \mathrm{ml}$ respectively; and served as positive controls. The working concentrations obtained were $16 \mu \mathrm{g} / \mathrm{ml}$ and $1 \mathrm{mg} / \mathrm{ml}$ prepared in culture broth without Tween 80 and then filter sterilized (Merck, Darmstadt, Germany). The plant extracts were dissolved at working concentrations of $4 \mathrm{mg} / \mathrm{ml}$ prepared in culture broth without Tween 80 . The assay was performed as described by Franzblau et al. [11] with slight modifications.

\section{Reverse transcriptase inhibition}

Reverse transcriptase enzyme is a potential therapeutic target against retrovirus infection since it plays a vital role in the conversion of viral ribonucleic acid (RNA) to complementary deoxyribonucleic acid (cDNA) [3]. The assay is based on the incorporation of dioxigenin and biotin labelled nucleotides into the new DNA synthesis. A commercially available kit was used and the assay was conducted as per the manufacturer's instructions (Roche Diagnostics; Risch-Rotkreuz, Switzerland).

\section{Statistical analyses}

All data were captured in Microsoft ${ }^{\circ}$ Excel spreadsheets (Office XP, 2010), where descriptive statistics such as the average, standard deviation, and coefficient of variance were preformed and for generating graphs. Student $t$-test was used for comparison of results obtained for Ziziphus mucronata and Pterocarpus angolensis Differences in the data were considered significant when $P<0.05$.

\section{Results}

\section{Cytotoxicity assay}

The results of cytotoxicity assays are shown in Fig. 1. Cytotoxicity was more pronounced in the U937 cells (A) than in the MeWo (B) and Vero cells (C). Pterocarpus angolensis was more cytotoxic than Ziziphus mucronata in the Vero and MeWo cells, however this was not apparent in the U937 cells. Together these results suggest some degree of selectivity towards U937 cells.

\section{Anti-Inflammatory activity}

Figure 2 illustrates the degree of inhibition in LPS stimulated nitric oxide production (A). It can be seen that neither of the two samples could reduce nitrate levels below the untreated LPS-stimulated cells. In the absence of LPS stimulation there was a significant increase in the production of $\mathrm{NO}(\mathrm{B})$.

\section{Anti-bacterial activity}

Table 1 shows the effects of plant extracts on bacterial growth results of Anti-bacterial. Absorbance readings of 96-well plates were measured at a wavelength of $600 \mathrm{~nm}$ before and after INT addition. Percentage inhibition for the plant extracts was not calculated as there was no observable inhibition of microbial growth. Minimal 


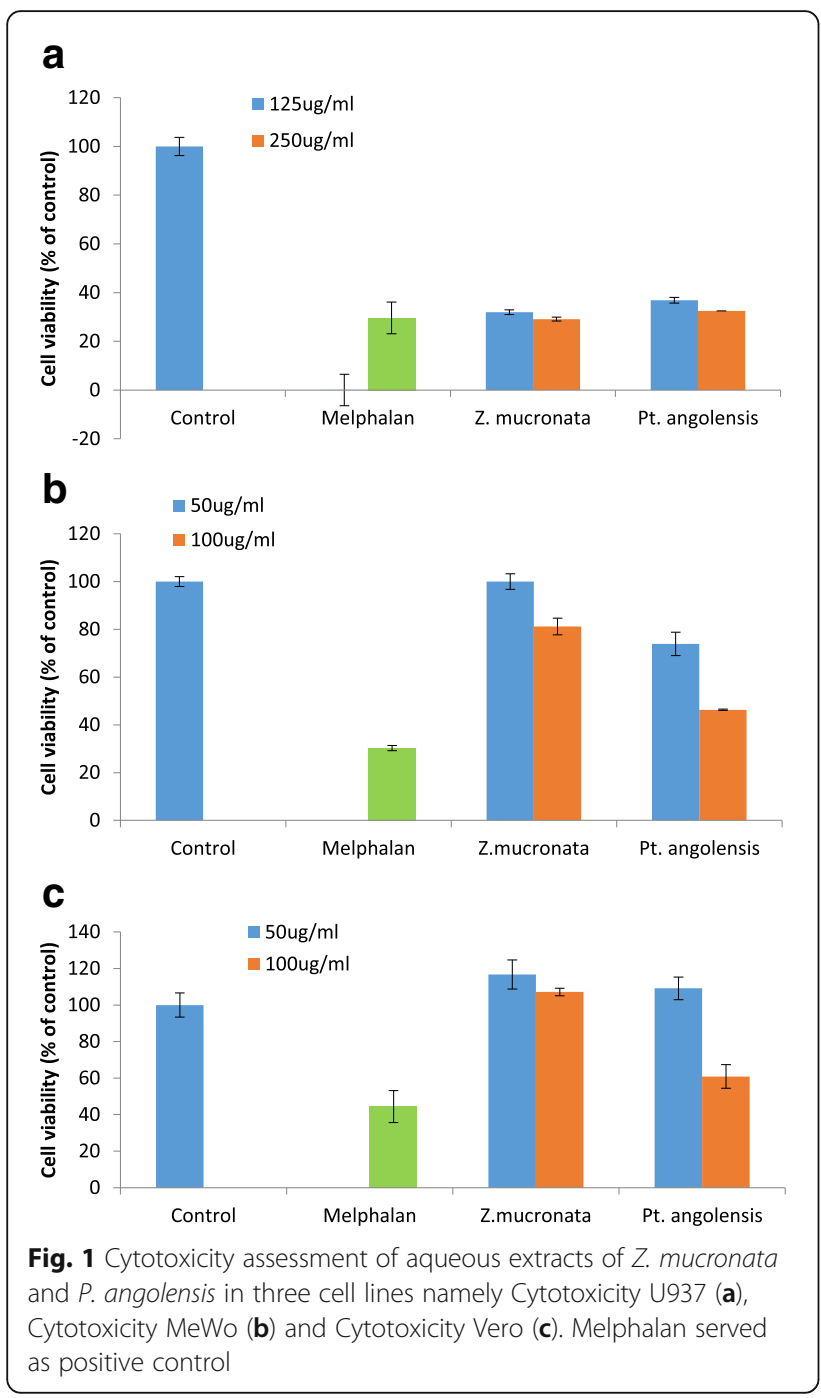

inhibitory concentration (MIC) values of the positive controls and plant extracts are summarized in Table 1.

\section{Anti-mycobacterial activity}

The results of the anti-microbial activity of A color change in CellTiter-Blue ${ }^{\circ}$ reagent was not clear for the higher plant extract concentrations, due to the extracts color. Plant extracts have shown anti-tuberculosis activity at concentrations $>500 \mu \mathrm{g} / \mathrm{mL}$. Positive controls' and plant extract MIC values are summarized in Table 2. Ethambutol dihydrochloride has shown no anti-tuberculosis activity against the M. tuberculosis H37 strain. This specific strain of $M$. tuberculosis might be resistant to ethambutol dihydrochloride.

\section{Reverse transcriptase inhibition}

Figure 3 illustrates the results of the two plant extracts activity on HIV replication. Both extracts revealed
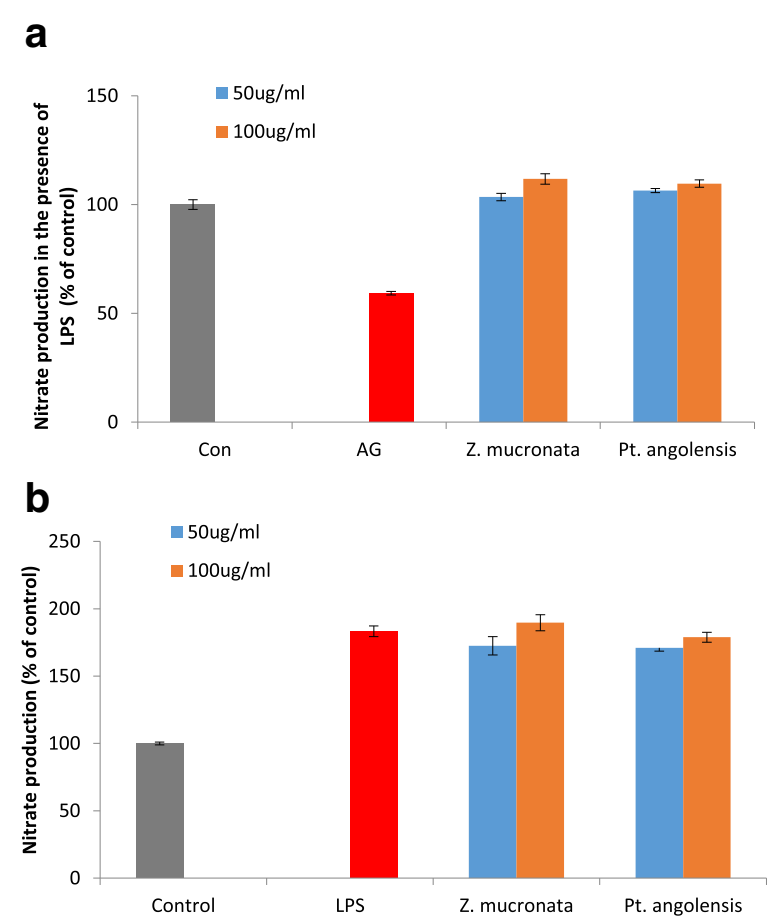

Fig. 2 Effect of plant extracts on the production of nitrate and cell viability in unstimulated macrophage (a) and in macrophage activation (b). Aminoguanidine, an inhibitor of iNOS expression serves as positive control to confirm the functionality of the assay. E.coli LPS, inducer of iNOS activity, was used to demonstrate macrophage activation capacity

inhibition of RT activity ( $>20 \%)$. Pterocarpus angolensis yielded strongest inhibition at both concentrations tested.

\section{Discussion}

For medicinal plants to be useful in clinical applications, the preparations must be selectively toxic to the targeted microorganisms or must at least interfere directly with a particular reaction pathway with minimal toxic effects to the host cells. The present study was aimed at comparing the in vitro activities of $Z$. mucronata and $P$. angolensis.

Our results demonstrated the selective toxicity effect of the two plants on cancerous cells. As observed in Fig. 1 , cytotoxicity was more pronounced in U937 $(P<$ 0.005 ) cells for both extracts seen as a decrease in viability. The observation suggests some degree of selectivity towards the U937 cells, thus it can be concluded that cytotoxicity of these extracts might be cell specific. The cytotoxic effects observed also in Mewo cells was also highly statistically significant $(P<0.005)$. Z. mucronata displayed the best inhibition on cancerous cells and stimulatory effect on normal cells. A study done by Bessong et al., [4] showed no cytotoxicity effects observed in Z. mucronata extract at the highest tested concentration $(400 \mu \mathrm{g} / \mathrm{ml})$ in HeLaP4 cells. Brine shrimp toxicity/lethality results as observed by McGaw et al. 
Table 1 MIC values of antibiotics and aqueous extracts of $Z$. mucronata and P. angolensis

\begin{tabular}{|c|c|c|c|c|}
\hline Microorganism & Positive control & $\begin{array}{l}\text { MIC } \\
(\mu \mathrm{g} / \mathrm{ml})\end{array}$ & $\begin{array}{l}\text { Z. mucronata } \\
\mathrm{MIC}(\mu \mathrm{g} / \mathrm{ml})\end{array}$ & $\begin{array}{l}\text { P. angolensi } \\
\mathrm{MIC}(\mu \mathrm{g} / \mathrm{ml})\end{array}$ \\
\hline Enterococcus faecalis & Vancomycin hydrochloride & 2 & N/A & N/A \\
\hline Escherichia coli & Gentamicin sulfate & 8 & N/A & N/A \\
\hline Klebsiella pneumonia & Gentamicin sulfate & 2 & N/A & N/A \\
\hline Salmonella enterica & Gentamicin sulfate/ imipenem dehydrate/ amicillin/ penicillin G/ chloramphenicol & Resistant $^{\mathrm{a}}$ & N/A & N/A \\
\hline Streptococcus agalactiae & Vancomycin hydrochloride & 2 & N/A & N/A \\
\hline
\end{tabular}

${ }^{a}$ Salmonella was resistant to gentamicin sulfate $(0.25$ to $64 \mu \mathrm{g} / \mathrm{ml})$, imipenem dehydrate, ampicillin, penicillin $\mathrm{G}$ and chloramphenicol $(0.25$ to $125 \mu \mathrm{g} / \mathrm{ml})$ N/A Not available

[20] showed $Z$. mucronata with minimal toxicity at $0.9 \mathrm{mg} / \mathrm{ml}$. P. angolensis hexane leaf extract showed toxicity of $3.8 \mathrm{mg} / \mathrm{ml}$ with increased toxicity as compared to $Z$. mucronata. Previous reports revealed that $P$. angolensis extracts possess anti-inflammatory activity [30]. Z mucronata also exhibited cytotoxic effect on brine shrimp at a concentration of $90.27 \mu \mathrm{g} / \mathrm{ml}$ [25].

This study has demonstrated firstly that $Z$. mucronata and $P$. angolensis do not inhibit $\mathrm{NO}$ production and secondly they do induce activation of macrophages. Macrophages are known to produce an extremely great number pro-inflammatory signals which can change the functionality of the surrounding cells. These includes production of nitric oxide which has been implicated in the ability to participate in diverse regulatory and cytotoxic action, it plays major role in mediating the human innate immunity [12]. The production of NO has been previously demonstrated to be of great importance in the regulation of both acute and chronic inflammation as well as host defense mechanisms against various pathogens $[6,21]$, though it might also induce toxic reactions against host tissues if produced in higher levels $[1,31]$. Our results indicate that the extracts have pro-inflammatory properties; however, it is necessary to confirm the absence of endotoxins which might present a similar effect. The nature of the extracts, in terms of their polysaccharide content, may also provide an indication as to their pro-inflammatory potential, as many plant polysaccharides are known to have immunomodulatory activity. A study done by Samie et al., [32] showed that the seven compounds isolated from bark of $P$. angolensis were less toxic when tested against human cells (HCT-8) with an inhibitory concentration of $175-375 \mu \mathrm{g} / \mathrm{ml}$.

The two plants tested did not have any activities on selected clinical bacterial species. The percentage for plant extract inhibition was not calculated as there was no observable microbial growth comparing the test and control wells. The results observed contradict the findings by Olajuyigbe and Afolayan [26]. The bacterial isolates (E. faecalis, E. coli, K. pneumoniae) exhibited varied degree of susceptibility with zones of inhibition ranging between 17 and $27 \pm 1.0 \mathrm{~mm}$, though the difference in results can be attributed to the extraction solvent they used. A study report published by Samie et al., [32] showed that ethanolic extracted compounds from $P$. angolensis inhibited bacterial growth of Staphylococcus aureus with median inhibitory concentration of $25 \mu \mathrm{g} / \mathrm{ml}$. The results obtained in this study are not surprising because previous reports have shown that certain plant water extracts do not possess any biological activity [17].

However, the same plant extracts tested against $M$. tuberculosis $\mathrm{H} 37$ demonstrated strong anti-TB activities at concentrations $>500 \mu \mathrm{g} / \mathrm{ml}$. Tuberculosis is regarded as one of the major health problem especially in developing countries and is listed as a leading cause of death worldwide. An estimation of about $80 \%$ individuals are diagnosed yearly $[7,8]$. Due to increase in multi drug resistance (MDR) and extensively drug resistance TB (XDR) strains of $M$. tuberculosis, the need of discovering newer anti-mycobacterial agents to eradicate the infections has increased. A study by Ibekwe et al., [15] showed that Pterocarpus osun Craib exhibited an MIC value of $1225 \mu \mathrm{g} / \mathrm{ml}$ against strain H37.

Furthermore, Z. mucronata and P. angolensis displayed anti-HIV replication activity (from 20 to $60 \%$ inhibition) with the activity of $P$. angolensis similar to that of Niverapine at $10 \mu \mathrm{M}$. Mulaudzi et al. [23] have classified four levels of RT enzyme inhibition for medicinal plant extracts; with activities below $20 \%$ classified as

Table 2 MIC values of antibiotics and aqueous extracts of $Z$. mucronata and $P$. angolensis

\begin{tabular}{lllll}
\hline Microorganism & Positive control & MIC $(\mu \mathrm{g} / \mathrm{ml})$ & $\begin{array}{l}\text { Z. mucronata } \\
\text { MIC }(\mu \mathrm{g} / \mathrm{ml})\end{array}$ & $\begin{array}{l}\text { P. angolensis } \\
\mathrm{MIC}(\mu \mathrm{g} / \mathrm{ml})\end{array}$ \\
\hline Mycobacterium tuberculosis & Ethambutol dihydrochloride & Not determined ${ }^{\mathrm{a}}$ & $>500 \mu \mathrm{gg} / \mathrm{ml}$ & $>500 \mu \mathrm{gg} / \mathrm{ml}$ \\
& Rifampicin & 0.5 & \\
\hline
\end{tabular}

${ }^{\mathrm{a}}$ Could not be determined: $M$. tuberculosis strain might be resistant 


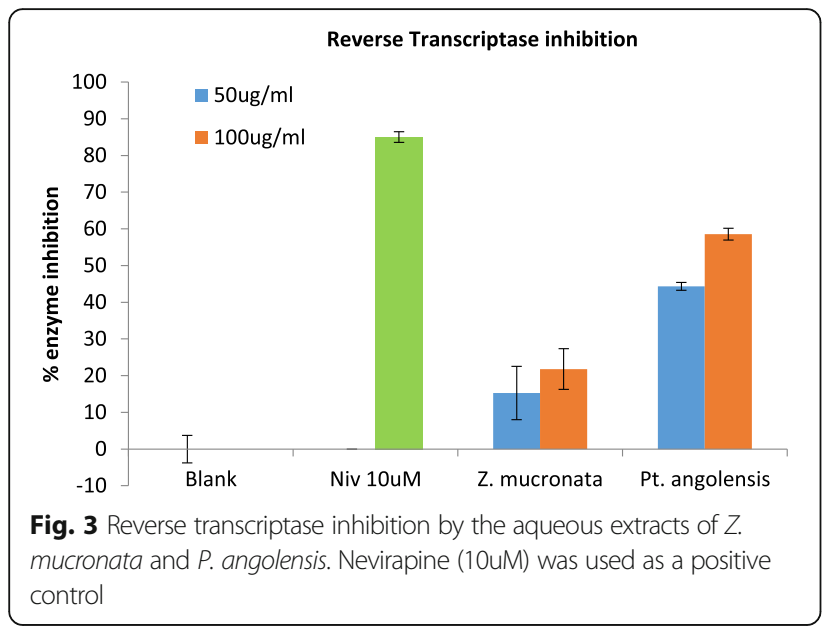

insignificant, $20-40 \%$ considered low activity, 40-70\% moderate, and $70-100 \%$ high activity. According to this classification the activity of $P$. angolensis is considered moderate and may thus warrant further dose response determination and calculation of an IC50 value. A study done by Bessong et al., 2005 showed RDDP IC 50 (77.5 and 81.5) and RNase $\mathrm{H} \mathrm{IC}_{50}$ (>100 and 75) activities of $Z$. mucronata for aqueous and methanol respectively; however the plant extracts were prepared from roots and leaves.

Natural products have been considered the first form of treatment in the treatment of human diseases. The use of such products has been in practice for centuries. The use of modern medicine has developed over the years through scientific evaluations and observational efforts of researchers. However, the basis of its development ought to be attributed to traditional medicine and therapies [27]. Nevertheless, ancient wisdom passed on from generation to generation will remain the basis of modern medicine and will forever be considered as one important source of future medicine and therapeutics.

\section{Conclusions}

Results obtained showed that both plants have selective anti-tumor activities with $P$. angolensis being toxic to normal cells at higher concentrations but displayed profound anti-HIV activity compared to $Z$. mucronata. The observed toxicity on malignant cell lines is to be investigated further for promising anti-cancer therapy drugs. The activities observed for the two extracts shows the importance role they can display in treatment of HIV/ AIDS thus reducing the burden of disease, with the sky rocketing pandemic of the infections in Sub-saharan Africa natural interventions are urgently needed to help alleviate this burden of disease.

\section{Abbreviations}

AIDS: Acquired immune deficiency syndrome; cDNA: Complementary deoxyribonucleic acid; DMEM: Dulbeco's modified eagle medium;
DMSO: Dimethylsulfoxide; DNA: Deoxyribonucleic acid; ELISA: Enzyme-linked immunosorbent assay; HIV: Human immunodeficiency virus; INT: 2-(4-iodophenyl)3-(4-nitrophenyl)-5-phenyl-2-H-tetrazolium; LPS: Lipopolysaccharide; MDR: Multi drug resistant; MH: Mueller Hinton; MIC: Minimal inhibitory concentration; MTT: Methylthiazol tetrazolium; NHLS: National health laboratory services; NMMU: Nelson Mandela Metropolitan University; NO: Nitric oxide; RNA: Ribonucleic acid; RPMl: Roosevelt Park Memorial Institute Medium; RT: Reverse transcriptase; XDR: Extensively drug resistant

\section{Acknowledgements}

The authors would like to acknowledge the work done by Prof M Van Der Venter and her Team at the NMMU in Port Elizabeth We also acknowledge funding contribution by the Research \& Innovation Directorate of the University of Venda. The assistance from the traditional healers (Mr Maphiri and Mr Munyai) is highly appreciated.

\section{Funding}

This work was supported by the University of Venda, Research and Innovation Directorate (S/15/MBY10) grants provided to Dr AN Traore a researcher in the Microbiology Department.

\section{Availability of data and material}

Data sharing not applicable.

\section{Authors' contributions}

MTS and MPT conducted interviews with traditional healers and collected the plant materials. ANT and MTS carried out laboratory work with assistance from Prof van de Venter and her team in NMMU. The remaining co-authors were involved in the write up based on their area of expertise. All the authors read and approved the final manuscript.

\section{Competing interests}

The authors declare that they have no competing interests.

\section{Consent of publication}

Not applicable.

\section{Ethics approval and consent to participate}

The experimental procedure were approved by the ethics committee of the University of Venda (SMNS/14/MBY/30/1210) and were accordance with international guidelines.

\section{Author details}

${ }^{1}$ Microbiology Department, University of Venda, Private Bag X5050, Thohoyandou, Limpopo Province, South Africa. ${ }^{2}$ Chemistry Department, University of Venda, Private Bag X5050, Thohoyandou, Limpopo Province, South Africa. ${ }^{3}$ Biochemistry Department, University of Venda, Private Bag X5050, Thohoyandou, Limpopo Province, South Africa. ${ }^{4}$ Botany Department, University of Venda, Private Bag X5050, Thohoyandou, Limpopo Province, South Africa. ${ }^{5}$ School of Mathematical and Natural Sciences, University of Venda, Private Bag X5050, Thohoyandou, Limpopo Province, South Africa.

Received: 3 November 2016 Accepted: 2 December 2016

Published online: 09 December 2016

\section{References}

1. Albina JE, Reichner JS. Nitric oxide in inflammation and immunity. New Hori. 1995;3:46-64.

2. Alkohafi A, Batshoun R, Owais N, Najib N. Biological activity of some Jordanian medicinal plant extracts. Filoterapia. 1996;68:435.

3. Baltimore D. RNA-dependant DNA, polymerase in virions of RNA tumour viruses. Nature. 1970;226:1209-11.

4. Bessong PO, Obi CL, Andreola M, Rojas LB, Pouysegu L, Igumbor E, Meyer JJM, Quideau S, Litvak S. Evaluation of selected South African medicinal plants for inhibitory properties against immunodeficiency virus type 1 reverse transcriptase and integrase. J Ethnopharmacol. 2005;99:83-91.

5. Cheikhyoussef A, Embashu W. Ethnobotanical knowledge on indigenous fruits in Ohangwena and Oshikoto regions in Northern Namibia. J Ethnobiol Ethnomed. 2012;9:34. 
6. Di Virgilio F. new pathways for reactive oxygen species generation in inflammation and potential novel pharmacological targets. Curr Pharm Des. 2004;10:1647-52.

7. Dye C, Scheele S, Dolin P, Pathania V, Raviglione MC. Global burden of tuberculosis: estimated incidence, prevalence, and mortality by country. J Am Med Ass. 1999;282:677-86.

8. Dye C. Global epidemiology of tuberculosis. Lancet. 2006;367:938-40.

9. Eloff JN. A sensitive and quick microplate method to determine the minimal inhibitory concentration of plant extracts for bacteria. Plant Medica. 1998;64:711-3.

10. Foden W, Potter L. Ziziphus mucronata Willd.subsp.mucronata. National assessment: Red list of South African plants version. 2005. http://redlist. sanbi.org/species.php?species=4058-4. Accessed 5 Jan 2016.

11. Franzblau SG, Witzig RS, McLaughlin JC, Torres P, Madico G, Hernandez A, Degnan MT, Cook MB, Quenzer VK, Ferguson RM, Gilman RH. Rapid, lowtechnology MIC determination with clinical Mycobacterium tuberculosis isolates by using the microplate Alamar Blue assay. J Clin Microbiol. 1998; 36(2):362-6.

12. Hickman-Davis JM, O'Reilly P, Davis K, Peti-Petendi J, Davis G, Young KR Devlin RB, Malalon S. Killing of Klebsiella pneumoniae by human alveolar macrophages. Am J Physiol Lung Cell Mol Physiol. 2002;286:994-56.

13. Huda-Faujan N, Noriham A, Norrakiah AS, Babji AS. Antioxidant activity of plants methanolic extracts containing phenolic compounds. Afri Biotechnol. 2009;8:484-9.

14. Hutchings A, Haxton Scott A, Lewis G, Cunningham A. Zulu Medicinal plants - an inventory. Pietermaritizburg: University of Natal Press; 1996. ISBN-0-869808931.

15. Ibekwe NN, Nvau JB, Oladosu PO, Usman AM, Ibrahim K, Boshoff HI, Dowd CS, Orisadipe AT, Aiyelaagbe O, Adesomoju AA, Barry CE, Okogun Jl. Some Nigerian anti-tuberculosis ethnomedicines: a preliminary efficacy assessment. J Ethnopharmacol. 2014;155(1):524-32

16. Klos M, van de Venter M, Milne PJ, Traore HN, Meyer D, Oosthuizen V. In vitro anti-HIV activityof five selected South Africanmedicinal plant extracts. J Ethnopharmacol. 2009;124:182-8.

17. Luseba D, Elgorashi EE, Ntloedibe DT, van Staden J. Antibacterial, antiinflammatory and mutagenic effects of some medicinal plants used in south Africa for treatment of wounds and retained placenta in livestock. SA J Bot. 2007;73:378-83.

18. Makgakga C. Usefeul plants of the Northern Province: a preliminary list of North Sotho plant names and their uses. Plantlife. 1995;13:27-9.

19. Maroyi A. Ethnobotanical study of medicinal plants used by people in Nhema communal area, Zimbabwe. J Ethnopharmacol. 2011;136:347-439.

20. McGaw LJ, Van der Merwe D, Eloff JN. In vitro anthelmintic, antibacterial and cytotoxic effects of extracts from plants used in South African ethnoveterinary medicine. Vet J. 2007;173:366-72.

21. Michael T, Feron O. Nitric oxide synthases: which, where, how, and why? J Clin Invest. 1997:100:2146-52.

22. Mosmann T. Rapid colorimetric assay for cellular growth and survival: application to proliferation and cytotoxicity assays. J Immunol Methods. 1983;65:55-63.

23. Mulaudzi RB, Ndlala AR, Kulkarni MG, Finnie JF, van Staden J. Antimicrobial properties and phenolic contents of medicinal plants used by the Venda people for conditions related to venereal disease. J Ethnopharmacol. 2011; 135:330-7.

24. National Reference Centre for African Traditional Medicines (NRCATM): A South African Model. Department of Health (DOH), Medical Research Council (MRC), Council for Scientific and Industrial Research (CSIR). 2004. Available Online: http://www.sahealthinfo.org/traditional.pdf. Accessed 1 Feb 2016.

25. Olajuyigbe OO, Afolayan AJ. In vitro ethnotherapeutic potential of acetone extract of the bark of Ziziphus mucronata Willd.subsp. mucronata Willd: Antimicrobial and toxicity evaluations. (2012) Afr J Biotechnol. 2012;11(103):16783-9.

26. Olajuyigbe $\mathrm{OO}$, Afolayan AJ. Evaluation of combination effects of ethanolic extract of Ziziphus mucronata Willd Subsp.mucronata Willd and antibiotics against clinically important bacteria. Sci World. 2013; dx.doi.org/10.1155/ 2013/769594.

27. Patwardhan $B$, Vaidya DB, Chonghade M. Ayuverda and natural products drug discovery. Curr Sci. 2004:86:789-99.

28. Pauli GF, Case RJ, Inui T, Wang Y, Cho S, Fischer NH, Franzblau SG. New perspectives on natural products in TB drug research. Life Sci. 2005;78:485-94.
29. Raimondo D, van Staden L, Foden W, Victor JE, Helme NA, Turner RC, Kamundi DA, Manyama PA. Red list of South African plants. 2009. http:// redlist.sanbi.org/species. Accessed 15 Jan 2016

30. Recio MC, Giner RM, Manez S, Rios L, Marston A, Hostettmann K. Screening of tropical medicinal plants for anti-inflammatory activity. Phytother Res. 1995;9(8):571-4.

31. Rothe $\mathrm{H}$, Kolb H. Strategies of protection from nitric oxide in islets inflammation. J Mol Med. 1999;77:40-4.

32. Samie A, Housein A, Lall N, Meyer JJM. Crude extracts of, and purified compounds from Pterocarpus angolensis, and the essential oil Lippia javanica: their in vitro cytotoxicities and activities against selected bacteria and Entamoeba histolytica. Ann Trop Med Parasitol. 2009;133(5):427-39.

33. Scott G, Springfield EP, Coldrey N. A pharmacognostical study of 26 South African plant species used as traditional medicines. Pharm Biol. 2004;42(3): I86-213.

34. Tschetsche R, Khokhar I, Spilles C, Radolf MV. Peptide alkaloids from Ziziphus spina-christi. Phytochemistry. 1974;13:1633-5.

35. Van Wyk BE, Gericke N. People's plants, a guide to usefull plants of Southern Africa. Pretoria: Briza publications; 2000. p. 351.

36. Venter F, Venter JA. Making the most of indigenous trees. Briza publications. 1996. p. 300

37. Watt JM, Breyer-Brandwijk MG. The medicinal and poisonous plants of Southern and Eastern Africa. 2nd ed. London: Livingstone; 1962.

\section{Submit your next manuscript to BioMed Central and we will help you at every step:}

- We accept pre-submission inquiries

- Our selector tool helps you to find the most relevant journal

- We provide round the clock customer support

- Convenient online submission

- Thorough peer review

- Inclusion in PubMed and all major indexing services

- Maximum visibility for your research

Submit your manuscript at www.biomedcentral.com/submit 